\title{
Kontribusi Kesiapan Guru dan Aktivitas Belajar Siswa Terhadap Hasil Belajar pada Pembelajaran Daring Jurusan Otomotif
}

\author{
Hendra Suheri ${ }^{1 *}$, Waskito ${ }^{2}$ (iD \\ 1,2 Fakultas Teknik, Universitas Negeri Padang, Indonesia \\ *Corresponding author:allbestpractice19@gmail.com
}

\begin{abstract}
Abstrak
Masih banyak guru yang belum konsisten dalam menerapkan pembelajaran daring kelas maya. Penelitian ini bertujuan untuk menganalisis kontribusi kesiapan guru dan aktivitas belajar siswa dalam menggunakan kelas maya terhadap hasil belajar siswa jurusan otomotif di SMKN. Penelitian ini adalah penelitian kuantitatif dengan jenis penelitian korelasional. Sampel penelitian terdiri dari 52 guru dan 52 siswa yang diperoleh berdasarkan teknik propotional random sampling. Data yang diperoleh melalui instrument kuesioner dilakukan uji persyaratan analisis dan kemudian dianalisis dengan menggunakan teknik deskriptif, teknik korelasi, regresi linear sederhana dan regresi ganda. Hasil analisis data menunjukkan bahwa: (1) kesiapan guru berkontribusi terhadap hasil belajar sebesar 18,2\%; (2) kontribusi aktivitas belajar siswa terhadap hasil belajar sebesar 27,1\%; dan (3) kontribusi kesiapan guru dan aktivitas belajar siswa terhadap hasil belajar secara bersama-sama sebesar 37,4\%. Berdasarkan hasil penelitian, dapat disimpulkan bahwa Kesiapan guru dan aktivitas belajar siswa memiliki kontribusi positif yang signifikan dan memiliki peran yang penting terhadap hasil belajar siswa jurusan otomotif dalam penggunaaan media kelas maya pada pembelajaran daring.
\end{abstract}

Kata kunci: Kesiapan Guru, Aktivitas Belajar

\section{Abstract}

There are still many teachers who have not been consistent in implementing virtual classroom online learning. This study aims to analyze the contribution of teacher readiness and student learning activities in using virtual classes to student learning outcomes in the automotive department at SMKN. This research is quantitative research with the type of correlational research. The research sample consisted of 52 teachers and 52 students who were obtained based on a proportional random sampling technique. The data obtained through the questionnaire instrument was tested for requirements analysis and then analyzed using descriptive techniques, correlation techniques, simple linear regression, and multiple regression. The results of data analysis show that: (1) teacher readiness contributes to learning outcomes by $18,2 \%$; (2) the contribution of student learning activities to learning outcomes is 27,1\%; and (3) the contribution of teacher readiness and student learning activities to learning outcomes together is 37,4\%. Based on the results of the study, it can be concluded that teacher readiness and student learning activities have a significant positive contribution and have an important role in the learning outcomes of students in the automotive department in the use of virtual classroom media in online learning.

\section{Keywords: Teacher Readiness, Student Learning Activities}

\section{INTRODUCTION}

Pada Abad 21 ini yang dikenal dengan abad teknologi, di mana berbagai aspek kehidupan berkembang sangat pesat, terutama bidang pendidikan. Guru maupun siswa dituntut untuk dapat mengoperasikan dan menggunakan teknologi sebaik-baiknya dalam proses pembelajaran yang dapat mempengaruhi hasil belajar siswa (Haka et al., 2020; Kencanawati et al., 2020; Widiastiti \& Sumantri, 2020). Hal tersebut sejalan dengan rata-rata kehidupan sehari-hari siswa pada era milenial sekarang ini yang selalu dekat dengan teknologi seperti gadget, smartphone dan lain sebagainya yang terkoneksi dengan jaringan internet. Pada proses pembelajaran di sekolah, guru menjadi salah satu faktor eksternal yang sangat mempengaruhi hasil belajar siswa, seperti penggunaan pendekatan, metode, maupun media pembelajaran yang digunakan. Oleh karena itu, sesuai dengan perkembangan zaman, guru dituntut untuk memanfaat teknologi dalam proses pembelajaran (Budarsini et al., 2018; Busyaeri et al., 2016; Hartati \& Novrika, 2018).

$\begin{array}{ll}\text { History: } & \\ \text { Received } & \text { : January 27, } 2021 \\ \text { Revised } & \text { : Januari 28, } 2021 \\ \text { Accepted } & \text { : April 26, 2021 } \\ \text { Published } & \text { : May 25, } 2021\end{array}$


Pembelajaran berbasis teknologi dapat diselenggarakan dalam berbagai model dengan memanfaatkan Teknologi Informasi dan Komunikasi (TIK) melalui audio/radio, video/TV, multimedia, serta pembelajaran dengan menggunakan media komputer dan internet (interconnection and networking) (Aisyi et al., 2013; Hamid, 2016; Sukmawati \& Nensia, 2019). Pembelajaran dengan menggunakan media komputer dan internet merupakan salah satu alternatif yang sangat potensial, di mana kebutuhan pendidikan yang telah mengglobal menuntut adanya percepatan dan perluasan akses yang tak terbatasi. Perkembangan TIK membawa perubahan dramatis dalam semua aspek kehidupan, termasuk di bidang pendidikan. Penerapan TIK telah melahirkan model baru dalam pembelajaran, misalnya munculnya online learning atau pembelajaran berbasis web. Online learning merupakan model pembelajaran dengan menggunakan jaringan internet sebagai saluran utama komunikasi dan interaksi pembelajaran dan biasanya memanfaatkan web.

Penggunaan internet dalam sistem pendidikan dapat berupa penggunaan internet sebagai media pembelajaran atau yang lebih dikenal sebagai sistem E-learning. Sistem Elearning ini merupakan proses penyampaian program pembelajaran, pelatihan atau pendidikan secara elektronik, yaitu melibatkan penggunaan komputer atau alat elektronik (misalnya telepon seluler) dalam berbagai cara untuk menyediakan bahan-bahan pelatihan, pendidikan atau pembelajaran (Pombo et al., 2012; Sutrisno et al., 2013). Sistem E-learning membuat siswa dapat berbagi materi, pertanyaan dengan guru secara langsung melalui media yang sama dengan guru. Sistem E-learning yang diharapkan dapat menjadi complement sistem pembelajaran konvensional memiliki manfaat dan kekurangan. Pada saat ini pembelajaran yang sudah menggunakan sistem E-learning adalah pembelajaran kelas maya. Kelas maya ini merupakan kelas yang diadakan tanpa tatap muka secara langsung antara pengajar dan yang menerima bahan ajar. Kelas maya ini membutuhkan koneksi internet, dimana pengajar menyediakan sebuah forum kepada para penerima bahan ajar dan melakukan diskusi seperti kegiatan belajar mengajar di kelas.

Kelas Maya merupakan salah satu fitur dalam Portal Rumah Belajar yang dikembangkan oleh Kemendikbud melalui Pusat Teknologi Informasi dan Komunikasi Pendidikan dan Kebudayaan (Pustekkom) untuk memfasilitasi pembelajaran jarak jauh secara online antara peserta didik dan pendidik. Strategi pembelajaran di Kelas Maya lebih bersifat konstruktivistik, yaitu pembelajaran aktif dan berpusat pada peserta didik sehingga mendorong keterampilan peserta didik. Selain banyak kelebihan yang didapat dengan pembelajaran online dalam sekolah, kekurangan dari E-learning ini adalah kurangnya sosialisasi antara guru dan siswa begitu juga antar siswa. Karena proses pembelajaran dilakukan secara online dapat diartikan letak geografis yang berbeda dari setiap pengguna. Hal ini dapat diatasi dengan tidak menghilangkannya pembelajaran di kelas dan memberikan tugas kelompok dalam kelas online sehingga antar siswa tetap dapat saling berkomunikasi, bekerjasama dan berbagi pendapat serta berdiskusi bersama dalam situasi lokasi dan tempat yang berbeda. Namun tidak serta merta pembelajaran online dapat langsung digunakan dalam suatu lingkungan sekolah, berhasil tidaknya pencapaian tujuan pendidikan banyak bergantung kepada bagaimana proses belajar yang dialami siswa. Dalam proses belajar yang berpengaruh bagi tujuan pendidikan yang berlangsung salah satu faktor psikologi yang ada didalamnya adalah kesiapan.

Kesiapan adalah keseluruhan kondisi seseorang yang membuatnya siap untuk memberi respons/jawaban di dalam cara tertentu terhadap suatu situasi (Ayuni et al., 2020; Wangid et al., 2014). Kesediaan untuk memberi response atau bereaksi. Kesediaan itu timbul dari dalam diri seseorang dan juga berhubungan dengan kematangan, karena kematangan yang berarti kesiapan untuk melaksanakan kecakapan. Kesiapan ini perlu diperhatikan dalam proses belajar, karena jika siswa belajar dan padanya sudah ada kesiapan, maka hasil belajarnya akan lebih baik. Faktor pendidik salah satunya terkait dengan sistem pembelajaran 
yang akan digunakan dalam proses mengajar. Dalam lingkungan sekolah siswa melakukan interaksi secara langsung dengan guru sehingga banyak pengetahuan guru mengenai siswanya.

Berdasarkan observasi dan pengamatan yang peneliti lakukan di SMK Negeri 2 Solok, peneliti menemukan informasi bahwa SMK N 2 Solok telah menerapkan pembelajaran berbasis daring dengan menggunakan E-learning dalam pelaksanaan pembelajaran khususnya pada masa pandemi Covid-19. Dimana SMKN 2 Solok telah menggunakan kelas maya rumah belajar besutan PUSTEKKOM KEMDIKBUD dalam pelaksanaan pembelajaran selama pandemi COVID-19, hal ini sudah berjalan semenjak bulan juli 2020. Namun fenomena negatif terjadi pada hasil belajar siswa pada saat pembelajaran menggunakan kelas maya dalam pembelajaran daring. Peneliti memperoleh informasi dan data banyak hasil belajar siswa pada jurusan otomotif yang rendah pada saat pelaksanaan pembelajaran daring dilaksanakan. Hal tersebut dilihat dari rata-rata hasil rapor tengah semester ganjil tahun 2020 siswa pada jurusan otomotif SMKN 2 Kota Solok. Dari jumlah total, rata-rata siswa yang memiliki hasil belajar/ pencapaian ketuntasan minimal hanya terdapat 60\%. Rekapitulasi data hasil belajar siswa Jurusan Teknik Otomotif pada pertengahan semester ganjil Tahun Pelajaran 2020/2021 dapat dilihat pada Tabel 1.

Tabel 1. Rekapitulasi Data Hasil Belajar Siswa Jurusan Teknik Otomotif Pada Pertengahan Semester Ganjil Tahun Pelajaran 2020/2021

\begin{tabular}{lccc}
\hline \multirow{2}{*}{ Nama Kelas } & \multirow{2}{*}{ KKM } & \multicolumn{2}{c}{ Persentase (\%) Hasil Belajar } \\
\cline { 3 - 4 } & & Kompeten & Tidak Kompeten \\
\hline TKR & 7,00 & 56,8 & 43,2 \\
TBO & 7,00 & 62,5 & 47,5 \\
\hline Rata-rata & $\mathbf{7 , 0 0}$ & $\mathbf{5 9 , 6 5}$ & $\mathbf{4 5 , 3 5}$ \\
\hline
\end{tabular}

Berdasarkan data tersebut, peneliti memperoleh informasi selama pengamatan, yang diasumsikan penyebab hasil belajar siswa rendah diantaranya adalah; (1) selama proses pembelajaran masih banyak guru yang belum konsisten dalam menerapkan pembelajaran daring kelas maya; (2) metode dan media pembelajaran yang digunakan guru kurang menarik perhatian siswa untuk ikut aktif dalam proses pembelajaran. Hal tersebut terjadi diasumsikan karena kurangnya kesiapan guru dalam menggunakan media pembelajaran berbasis teknologi dan memanfaatkan fasilitas yang tersedia. Dengan demikian dapat menjadikan (3) peserta didik kesulitan dalam memahami dan menganalisis materi pembelajaran yang diberikan oleh guru; (4) masih banyak terdapat siswa yang tidak mengikuti pembelajaran daring secara penuh, hanya sekedar mengambil presensi pada pembelajaran yang diberikan guru; (5), aktivitas belajar kebanyakan siswa cenderung tidak berjalan aktif dan memperhatikan materi yang disampaikan dalam pembelajaran, hal tersebut disimpulkan karena terdapat beberapa siswa ditemukan menggunakan smartphone di luar konteks pembelajaran pada saat proses pembelajaran berlangsung sebagaimana diinformasikan oleh ketua jurusan otomotif saat pembinaan siswa dalam pembelajaran daring. Serta minimnya aktivitas diskusi dan tanya jawab dalam forum diskusi kelas maya yang merupakan salah satu bagian dari portal pembelajaran kelas maya.

Hasil belajar merupakan hal yang sangat penting dalam pendidikan dan dapat dipandang sebagai salah satu ukuran keberhasilan siswa dalam pendidikan di sekolah. Hasil belajar ini dijadikan pedoman atau bahan pertimbangan dalam menentukan kemampuan siswa. Usaha untuk meningkatkan hasil belajar menuntut model pembelajaran yang mendukung dan adanya partisipasi berbagai pihak yang terkait agar mengarahkan perhatiannya kepada usaha peningkatan mutu pendidikan. Hasil belajar yang dicapai siswa 
dipengaruhi oleh dua faktor. Faktor dalam diri siswa yang merupakan perubahan kemampuan yang dimilikinya dan faktor diluar diri siswa yaitu lingkungan yang paling dominan berupa kualitas pembelajaran. Salah satu faktor yang dapat mempengaruhi kualitas pembelajaran yang berada diluar diri siswa adalah guru. Guru sejatinya dapat membimbing, memfasilitasi dan mengarahkan aktivitas belajar siswa.

Aktivitas belajar siswa selama proses pembelajaran merupakan salah satu indikator adanya keinginan siswa untuk belajar. Kegiatan aktivitas yang dimaksud adalah kegiatan yang sejalan dengan proses pembelajaran, seperti bertanya, mengajukan pendapat, mengerjakan tugas-tugas, serta menjawab pertanyaan guru dengan baik (Jannah \& Mudjiran, 2019; Ningsih et al., 2019; Sariayu \& Miaz, 2020). Semua ciri perilaku tersebut dapat ditinjau dari dua segi, yaitu dari segi proses dan dari segi hasil. Aktivitas yang timbul dari siswa akan mengakibatkan terbentuknya pengetahuan dan keterampilan yang akan mengarah pada peningkatan prestasi. Aktivitas siswa dalam pembelajaran dapat menyebabkan pembelajaran di sekolah menjadi lebih hidup sebagaimana aktivitas dalam kehidupan di masyarakat karena siswa aktif dalam belajar (mencari pengalaman) dan langsung mengalami sendiri kegiatan pembelajaran.

Pembelajaran dilaksanakan secara realistis dan konkret karena para siswa beraktifitas menurut minat dan kemampuannya sendiri untuk mengembangkan seluruh aspek pribadi siswa sehingga dapat mengembangkan pemahaman dan berpikir kritis siswa. Sejalan dengan hal tersebut, keaktifan siswa dalam proses pembelajaran dapat menciptakan proses kerja sama yang harmonis di kalangan siswa dan juga memunculkan disiplin kelas dengan wajar, serta membuat suasana belajar menjadi demokratis dan menyenangkan. Belum ada penelitian mendalam mengenai analisis kontribusi kesiapan guru dan aktivitas belajar siswa terhadap hasil belajar pada pembelajaran daring di tingkat sekolah menengah atas.

Beberapa penelitian yang relevan dengan penelitian ini seperti yang dilakukan oleh (Nuraini et al., 2018) yang menemukan bahwa terdapat pengaruh dan hubungan yang positif dengan kategori kuat antara aktivitas belajar siswa dan hasil belajar pada mata pelajaran kimia kelas X SMA. Kemudian penelitian yang dilakukan oleh (Ma et al., 2021) menemukan bahwa a kesiapan guru ekonomi dalam menghadapi online learning di Kota Ende berkisar 61,11-79,17 dengan kategori siap dan sangat siap. Tujuan penelitian ini menganalisis kontribusi kesiapan guru dan aktivitas belajar siswa dalam menggunakan kelas maya terhadap hasil belajar siswa jurusan otomotif di SMKN.

\section{MATERIALS AND METHODS}

Penelitian ini adalah penelitian kuantitatif dengan jenis penelitian korelasional. Penelitian ini dilaksanakan di SMK Negeri 2 Kota Solok pada siswa kelas XI jurusan Teknik Otomotif Kendaraan Ringan semester Ganjil tahun pembelajaran 2020/2021, dan semua guru yang mengajar di jurusan Teknik Otomotif dengan jumlah total populasi sebesar 121 orang yang terdiri dari 60 guru dan 61 siswa. Dari total populasi tersebut diperoleh sampel sebesar 104 sampel yang terdiri dari 52 guru dan 52 siswa. Peneliti mengambil sampel dalam penelitian ini menggunakan teknik proportional Random Sampling, yakni sampel diambil dari anggota populasi secara acak. Data dianalisis melalui pengujian persyaratan analisis yang meliputi uji normalitas, uji linearitas dan uji independensi, dan pengujian hipotesis.

\section{RESULTS AND DISCUSSION}

\section{Uji Normalitas}

Hasil pengujian normalitas, dapat dilihat pada Tabel 2. Berdasarakan Tabel 2, dapat dilihat bahwa skor signifikansi untuk variabel independen yang terdiri dari Kesiapan guru 
$\left(\mathrm{X}_{1}\right)$ sebesar 0,953 dan Aktivitas Belajar Siswa $\left(\mathrm{X}_{2}\right)$ sebesar 0,535. Sedangkan untuk variabel dependen yakni Hasil Belajar (Y) sebesar 0,655. Nilai signifikansi Alpha $(\alpha)$ yang dianut adalah 0,05 . Karena skor signifikansi untuk seluruh variabel yang diperoleh lebih besar dari 0,05 maka dapat disimpulkan bahwa data semua variabel berdistribusi normal. Kemudian selanjutnya dilakukan uji linieritas. Hasil uji linieritas dapat dilihat pada Tabel 3.

Tabel 2. Hasil Uji Normalitas

\begin{tabular}{llccc}
\hline & & $\begin{array}{c}\text { Kesiapan } \\
\text { Guru }\end{array}$ & $\begin{array}{c}\text { Aktivitas } \\
\text { Belajar Siswa }\end{array}$ & $\begin{array}{c}\text { Hasil } \\
\text { Belajar }\end{array}$ \\
\hline $\mathbf{N}$ & & $\mathbf{5 2}$ & $\mathbf{5 2}$ & $\mathbf{5 2}$ \\
\hline \multirow{2}{*}{ Normal Parameters } & Mean & 141,42 & 183,25 & 71,63 \\
& Std. Deviation & 6,878 & 6,902 & 5,664 \\
Most Extreme & Absolute & 0,071 & 0,101 & 0,084 \\
Differences & Positive & 0,062 & 0,096 & 0,078 \\
Kolmogorov-Smirnov Z & Negative & $-0,071$ & $-0,101$ & $-0,084$ \\
Asymp. Sig. (2-tailed) & & 0,515 & 0,728 & 0,606 \\
\hline
\end{tabular}

Tabel 3. Hasil Uji Linieritas

\begin{tabular}{|c|c|c|c|c|c|c|c|}
\hline & & & $\begin{array}{c}\text { Sum of } \\
\text { Squares }\end{array}$ & df & $\begin{array}{c}\text { Mean } \\
\text { Square }\end{array}$ & $\mathbf{F}$ & Sig. \\
\hline \multirow{5}{*}{$\mathrm{Y} * \mathrm{X} 1$} & \multirow{3}{*}{$\begin{array}{l}\text { Between } \\
\text { Groups }\end{array}$} & (Combined) & 888,808 & 25 & 35,552 & 1,237 & 0,297 \\
\hline & & Linearity & 297,375 & 1 & 297,375 & 10,347 & 0,003 \\
\hline & & $\begin{array}{l}\text { Deviation from } \\
\text { Linearity }\end{array}$ & 591,433 & 24 & 24,643 & 0,857 & 0,646 \\
\hline & Within Groups & & 747,250 & 26 & 28,740 & & \\
\hline & Total & & 1636,05 & 51 & & & \\
\hline
\end{tabular}

Berdasarkan Tabel 3, dapat dijelaskan bahwa nilai signifikan linearitas (Deviation from Linearity) $\mathrm{X}_{1}$ terhadap $\mathrm{Y}$ diperoleh nilai sebesar 0,646. Karena nilai sig. deviation from linearity > 0,05 maka dapat disimpulkan bahwa antara variabel Kesiapan Guru ( $\left.\mathrm{X}_{1}\right)$ dengan variabel Hasil Belajar (Y) terdapat hubungan yang linear. Selain itu, karena nilai linearity yang diperoleh sebesar 0,003 lebih kecil dari 0,05 dapat disimpulkan bahwa hubungan antar kedua variabel tersebut linier signifikan. Selanjutnya ialah uji Independensi. Hasil uji independensi dapat dilihat pada Tabel 4. Berdasarkan Tabel 4 dapat diketahui bahwa hasil korelasi (r) antara variabel Kesiapan Guru $\left(\mathrm{X}_{1}\right)$ dan Aktivitas Belajar Siswa $\left(\mathrm{X}_{2}\right)$ diperoleh nilai sebesar 0,217 dan probabilitas signifikansi $(p)$ sebesar 0,121 yang lebih besar dari 0,05. Hasil tersebut menunjukkan bahwa tidak terjadi korelasi antara variabel $\mathrm{X}_{1}$ dengan $\mathrm{X}_{2}$. Dengan demikian, hubungan variabel Kesiapan Guru $\left(\mathrm{X}_{1}\right)$ dengan Aktifitas Belajar Siswa $\left(\mathrm{X}_{2}\right)$ adalah independen. Selanjutnya ialah dilakukan uji hipotesis.

Tabel 4. Hasil Uji Independensi

\begin{tabular}{llcc}
\hline Correlations & Kesiapan Guru & $\begin{array}{c}\text { Aktivitas } \\
\text { Belajar Siswa }\end{array}$ \\
\hline \multirow{2}{*}{ Kesiapan Guru } & Pearson Correlation & 1 & 0,217 \\
& Sig. (2-tailed) & & 0,121 \\
Aktivitas Belajar Siswa & N & 52 & 52 \\
& Pearson Correlation & 0,217 & 1
\end{tabular}




\begin{tabular}{lccc}
\hline Correlations & Kesiapan Guru & $\begin{array}{c}\text { Aktivitas } \\
\text { Belajar Siswa }\end{array}$ \\
\hline & Sig. (2-tailed) & 0,121 & \\
$\mathrm{~N}$ & 52 & 52 \\
\hline
\end{tabular}

\section{Uji Hipotesis}

Kriteria pengujian atau dasar pengambilan keputusan adalah jika nilai $t_{\text {hitung }}>\mathrm{t}_{\text {Tabel }}$ atau nilai signifikansi probabilitas $<$ Alpha $(0,05)$, maka $\mathrm{H}_{0}$ ditolak dan jika nilai $\mathrm{t}_{\text {hitung }}<\mathrm{t}_{\text {Tabel }}$ atau nilai signifikansi probabilitas $>$ Alpha $(0,05)$ maka $\mathrm{H}_{0}$ diterima. Uji hipotesis dilakukan dengan bantuan proram SPSS versi 25.00. Berdasarkan hasil analisis yang dilakukan diperoleh nilai $t_{\text {hitung }}=3,333>t_{\text {tabel }}=1,677$ dan taraf signifikansi sebesar $0,002<$ signifikansi $\alpha$ : 0,05 . Hal tersebut menunjukkan bahwa hipotesis $\left(\mathrm{H}_{\mathrm{a}}\right)$ diterima, yaitu Terdapat hubungan positif yang signifikan antara kesiapan guru dengan hasil belajar. Kemudian Berdasarkan hasil analisis korelasi sebesar 0,426 dapat diperoleh besarnya nilai koefisien determinan $\left(\mathrm{r}^{2}\right)$ adalah 0,182 maka besar kontribusi kesiapan guru terhadap hasil belajar adalah sebesar $18,2 \%$. Berdasarkan hasil analisis yang dilakukan diperoleh nilai $t_{\text {hitung }}=4,316>t_{\text {tabel }}=1,677$ dan taraf signifikansi sebesar $0,000<$ signifikansi $\alpha$ : 0,05 . Hal tersebut menunjukkan bahwa hipotesis $\left(\mathrm{H}_{\mathrm{a}}\right)$ diterima, yaitu Terdapat hubungan positif yang signifikan antara aktivitas belajar siswa dengan hasil belajar. Kemudian Berdasarkan hasil analisis korelasi sebesar 0,521 dapat diperoleh besarnya nilai koefisien determinan $\left(\mathrm{r}^{2}\right)$ adalah 0,271 maka besar kontribusi kesiapan guru terhadap hasil belajar adalah sebesar $27,1 \%$.

Kriteria pengujian atau dasar pengambilan keputusan adalah jika nilai $\mathrm{F}_{\text {hitung }}>\mathrm{F}_{\text {Tabel }}$ atau nilai signifikansi probabilitas $(p)<$ Alpha: 0,05 maka $\mathrm{H}_{0}$ ditolak dan jika nilai $\mathrm{F}_{\text {hitung }}<$ $\mathrm{F}_{\text {Tabel }}$ atau nilai signifikansi probabilitas $(p)>$ Alpha: 0,05 maka $\mathrm{H}_{0}$ diterima. Berdasarkan hasil analisis yang dilakukan diperoleh nilai $F_{\text {hitung }}=14,656>F_{\text {tabel }}=3,185$ dan taraf signifikansi sebesar $0,000<$ signifikansi $\alpha$ : 0,05 atau dalam taraf kepercayaan $95 \%$. Hal tersebut menunjukkan bahwa hipotesis $\left(\mathrm{H}_{0}\right)$ ditolak dan $\left(\mathrm{H}_{\mathrm{a}}\right)$ diterima, yaitu terdapat hubungan positif yang signifikan antara kesiapan guru dan aktivitas belajar siswa secara bersama-sama dengan hasil belajar. Kemudian Berdasarkan hasil analisis korelasi ganda diperoleh koefisien korelasi (r) sebesar 0,612 dan besarnya nilai koefisien determinan $\left(\mathrm{r}^{2}\right)$ adalah 0,374. Maka besar kontribusi kesiapan guru dan aktivitas belajar secara bersama-sama terhadap hasil belajar adalah sebesar 37,4\% yang terdiri dari sumbangan efektif masingmasing variabel independen sebesar 14,0\% dari kesiapan guru dan 23,4\% dari aktivitas belajar siswa.

\section{Pembahasan}

Hasil penelitian pertama, meunjukkan bahwa kesiapan guru memiliki hubungan positif dan signifikan dengan hasil belajar yang dibuktikan dengan koefisien korelasi sebesar 0.426 dan koefisien regresi $\mathrm{X}_{1}$ dengan $\mathrm{Y}$ yang diperoleh sebesar 0.351 dengan nilai $\mathrm{t}_{\text {hitung }}$ sebesar 3,333 serta nilai signifikansi sebesar 0,002 yang lebih kecil dari taraf signifikansi $\alpha$ : 0,05. Hasil ini juga mengisyaratkan bahwa semakin baik kesiapan guru dalam melaksanakan proses pembelajaran dalam penggunaan kelas maya maka hasil belajar siswa kelas XI pada mata pelajaran Kompetensi Keahlian (C3) Jurusan Teknik Otomotif di SMKN 2 Kota Solok juga akan menjadi lebih baik. Hubungan yang terjadi masih dalam kategori sedang. Hal ini dikarenakan kesiapan guru memberikan dampak positif terhadap hasil belajar karena terlihat dari siapnya guru dalam menyiapkan proses pembelajaran (Alwiyah \& Imaniyati, 2018).

Kedua, aktivitas belajar siswa $\left(\mathrm{X}_{2}\right)$ memberikan kontribusi yang signifikan terhadap peningkatan hasil belajar (Y) dikarenakan aktivitas belajar memiliki hubungan yang positif dan signifikan dengan hasil belajar yang dibuktikan dengan perolehan nilai koefisien korelasi sebesar 0.521 dan koefisien regresi $\mathrm{X}_{2}$ dengan $\mathrm{Y}$ yang diperoleh sebesar 0.428 dengan nilai 
$t_{\text {hitung }}$ sebesar 4,316 serta nilai signifikansi sebesar 0,000 yang lebih kecil dari taraf signifikansi $\alpha$ : 0,05. Hasil ini juga mengisyaratkan bahwa jika aktivitas belajar siswa mengalami peningkatan, maka hasil belajar siswa kelas XI pada mata pelajaran Kompetensi Keahlian (C3) Jurusan Teknik Otomotif di SMKN 2 Kota Solok juga akan mengalami peningkatan, begitu juga sebaliknya. Hal ini dikarenakan Aktivitas belajar merupakan kegiatan belajar yang harus dilaksanakan dengan giat, rajin, selalu berusaha dengan sungguhsungguh melibatkan fisik maupun mental secara optimal yang meliputi visual activities, oral activities, listening activities, writing activities, drawing activities, motor activities, mental activities, emosional activities supaya mendapat prestasi yang gemilang dan tentu ini berdampak pada peningkatan hasil belajar (Jannah \& Mudjiran, 2019; Ningsih et al., 2019; Sariayu \& Miaz, 2020).

Ketiga, kesiapan guru $\left(\mathrm{X}_{1}\right)$ dan aktivitas belajar siswa $\left(\mathrm{X}_{2}\right)$ secara bersama-sama memberikan kontribusi yang signifikan terhadap peningkatan hasil belajar (Y) 37,4\%. Hasil analisis ini juga memperlihatkan bahwa kesiapan guru dan aktivitas belajar siswa secara bersama-sama memiliki hubungan positif dan signifikan terhadap hasil belajar yang termasuk dalam kategori kuat yang dibuktikan dengan perolehan koefisien korelasi sebesar 0.612 dengan koefisien determinan $\left(\mathrm{r}^{2}\right)$ sebesar 0,374 dan $\mathrm{F}_{\text {hitung }}$ sebesar 14,656 ( $\mathrm{F}_{\text {hitung }}>\mathrm{F}_{\text {Tabel }}$ $3,185)$ dengan signifikansi $(p)$ sebesar $0,000(p<0,05)$. Oleh karena itu, apabila kesiapan guru dan aktivitas belajar siswa secara bersama-sama mengalami peningkatan, maka hasil belajar siswa kelas XI pada mata pelajaran Kompetensi Keahlian (C3) Jurusan Teknik Otomotif di SMKN 2 Kota Solok juga akan mengalami peningkatan, begitu juga sebaliknya Kemudian berdasarkan hasil analisis sumbangan relative (SR) dan sumbangan efektif (SE), diketahui bahwa variabel Aktivitas Belajar Siswa (62,54\% dan 37,46\%) memberikan kontribusi (sumbangan) lebih dominan sebesar dibandingkan dengan Kesiapan Guru (23,4\% dan 14\%). Hal itu dikarenakan ketika guru sudah siap dengan segala perlengkapan yang akan digunakan dalam proses pembelajaran, hal itu juga akan berdampak pada aktivitas belajar siswa yang maksimal. Kedua hal itu jika sudah dilakukan secara maksimal, maka akan berdampak positif terhadap hasil belajar.

\section{CONCLUSION}

Kesiapan guru dan aktivitas belajar siswa memiliki kontribusi positif yang signifikan dan memiliki peran yang penting terhadap hasil belajar siswa jurusan otomotif dalam penggunaaan media kelas maya pada pembelajaran daring.

\section{REFERENCES}

Aisyi, F. K., Elvyanti, S., Gunawan, T., \& Mulyana, E. (2013). Pengembangan Bahan Ajar Tik Smp Mengacu Pada Pembelajaran Berbasis Proyek. Invotec, IX(2), 117-128. https://doi.org/10.17509/invotec.v9i2.4861.

Alwiyah, D., \& Imaniyati, N. (2018). Keterampilan Mengajar Guru Dan Kesiapan Belajar Siswa Sebagai Determinan Terhadap Hasil Belajar Siswa. Jurnal MANAJERIAL, 17(1), 95. https://doi.org/10.17509/manajerial.v17i1.9767.

Ayuni, D., Marini, T., Fauziddin, M., \& Pahrul, Y. (2020). Kesiapan Guru TK Menghadapi Pembelajaran Daring Masa Pandemi Covid-19. Jurnal Obsesi : Jurnal Pendidikan Anak Usia Dini, 5(1), 414. https://doi.org/10.31004/obsesi.v5i1.579.

Budarsini, K. P., Suarsana, I. M., \& Suparta, I. N. (2018). Model diskursus multi representasi dan kemampuan pemahaman konsep matematika siswa sekolah menegah pertama. Pythagoras: Jurnal Pendidikan Matematika, 13(2), 110-118. https://doi.org/10.21831/pg.v13i2.20047. 
Busyaeri, A., Udin, T., \& Zaenudin, A. (2016). Pengaruh Penggunaan Video Pembelajaran Terhadap Peningkatan Hasil Belajar Mapel IPA di Min Kroya Cirebon. Al Ibtida: Jurnal Pendidikan Guru MI, 3(1), 116-137. https://doi.org/10.24235/al.ibtida.snj.v3i1.584.

Haka, N. B., Anggita, L., Anggoro, B. S., \& Hamid, A. (2020). Pengaruh Blended Learning Berbantukan Google Classroom Terhadap Keterampilan Berpikir Kreatif dan Kemandirian Belajar Peserta Didik. Edu Sains Jurnal Pendidikan Sains \& Matematika, 8(1), 1-12. https://doi.org/10.23971/eds.v8i1.1806.

Hamid, M. A. (2016). Pengembangan Instrumen Penilaian Hasil Belajar Siswa Berbasis TIK pada Pembelajaran Dasa./http://dx.doi.org/10.30870/volt.v1i1.822.

Hartati, S., \& Novrika, G. V. (2018). Using educational video to promoting listening skill children of 5-6 years old. Early Childhood Education Journal of Indonesia, 1(1), 2735. https://journal.unnes.ac.id/sju/index.php/eceji/article/view/23987/11097.

Jannah, N. H., \& Mudjiran, M. (2019). Pengaruh Model Pembelajaran Kooperatif Tipe Think Pair Share Terhadap Aktivitas dan Hasil Belajar Peserta Didik. Jurnal Basicedu, 3(4), 2125-2129. https://doi.org/10.33627/ge.v2i2.23.

Kencanawati, S. A. M. M., Sariyasa, S., \& Hartawan, I. G. N. Y. (2020). Pengaruh penerapan model pembelajaran SAVI (Somatic, Auditory, Visual, Intellectual) terhadap kemampuan berpikir kreatif matematis. Pythagoras: Jurnal Pendidikan Matematika, 15(1), 13-23. https://doi.org/10.21831/pg.v15i1.33006.

Ma, S. H. G., Parera, H. R., \& Amrin, S. (2021). Kesiapan Guru Ekonomi dalam Menghadapi Online Learning Di Kota Ende. Cetta: Jurnal Ilmu Pendidikan, 4(1), 33-46. http://jayapanguspress.penerbit.org/index.php/cetta/article/view/1232.

Ningsih, S. R., Miaz, Y., \& Zikri, A. (2019). Model Discovery Learning untuk Meningkatkan Aktivitas dan Hasil Belajar Tematik Terpadu di Sekolah Dasar. Jurnal Basicedu, 3(4), 1065-1072. https://doi.org/10.31004/basicedu.v3i4.203.

Nuraini, N., Fitriani, F., \& Fadhilah, R. (2018). Hubungan Antara Aktivitas Belajar Siswa dan Hasil Belajar pada Mata Pelajaran Kimia Kelas X SMA Negeri 5 Pontianak. ARRAZI Jurnal Ilmiah, 6(1). https://doi.org/10.29406/arz.v6i1.939.

Pombo, L., Smith, M., Abelha, M., Caixinha, H., \& Costa, N. (2012). Evaluating an online emodule for Portuguese primary teachers: trainees' perceptions. Technology, Pedagogy and Education, 21(1), 21-36. https://doi.org/10.1080/1475939X.2011.589156.

Sariayu, M. R., \& Miaz, Y. (2020). Peningkatan Aktivitas Belajar Siswa Melalui Model Think Pair Share di Sekolah Dasar. Jurnal Basicedu, 4(2), 295-305. https://doi.org/10.31004/basicedu.v4i2.337.

Sukmawati, S., \& Nensia, N. (2019). The Role of Google Classroom in ELT. International Journal for Educational and Vocational Studies, 1(2), 142-145. https://doi.org/10.29103/ijevs.v1i2.1526.

Sutrisno, T., Agung, Y. A., Tri Sutrisno, \& Yudha Anggana Agung. (2013). Pengembangan Media Videoscribe Berbasis E-Learning Pada Mata Pelajaran Komunikasi Data dan Interface Di SMK Sunan Drajat Lamongan. Jurnal Pendidikan Teknik Elektro, 05(03), 1068-1074.

Wangid, M. N., Mustadi, A., Erviana, V. Y., \& Arifin, S. (2014). Kesiapan Guru Sd Dalam Pelaksanaan Pembelajaran Tematik-Integratif Pada Kurikulum 2013 Di Diy. Jurnal Prima Edukasia, 2(2), 175. https://doi.org/10.21831/jpe.v2i2.2717.

Widiastiti, N. L. A., \& Sumantri, M. (2020). Model Quantum Teaching Berbasis Pendidikan Karakter Terhadap Motivasi Belajar IPA. Jurnal Pedagogi Dan Pembelajaran, 3(2), 303. https://doi.org/10.23887/jp2.v3i2.26628. 